\title{
Unaccompanied minor asylum seekers - processes of subject formation and feelings of belonging in the context of educational experiences in Switzerland
}

\author{
Barbara Bitzi and Sara Landolt \\ Department of Geography, University of Zurich, Zurich, 8057, Switzerland \\ Correspondence to: Sara Landolt (sara.landolt@geo.uzh.ch)
}

Received: 5 October 2016 - Revised: 8 April 2017 - Accepted: 10 April 2017 - Published: 16 May 2017

\begin{abstract}
This article addresses unaccompanied minor asylum seekers' (UAMs) educational experiences in Switzerland. Drawing on ethnographic research we explore what it means for UAMs to get an education and how having access or not having access to particular forms and spaces of education plays a part in the process of their subject formations. We get insights into such processes in diverse spaces of education and in phases of transition between them. We point out how educational arrangements can produce feelings of belonging and non-belonging and highlight that these feelings are entangled with life experiences and the responsibilities of UAMs in their daily lives in Switzerland. We argue that although at first glance the category "unaccompanied minor asylum seeker" seems to dominate and determine the formation of a possible educational subject and feelings of belonging for UAMs, the subject formation and feelings of belonging in the highly regulated field of UAMs' education are far more complex and fluid. To capture this complexity, we draw on geographies of education and understand spaces of education as connected to other spaces as UAMs' learning and educational processes are entangled with the demands of their everyday lives.
\end{abstract}

\section{Introduction}

Barbara: If you could change something about your life in Switzerland, at Waldblick, what would you change?

Thomas $^{1}$ (16, from Afghanistan): I'd go to the regular school [instead of the internal school], in order to have a better future.

This short sequence stems from an interview with Thomas, a 16-year old unaccompanied minor asylum seeker (UAM) ${ }^{2}$ living at Waldblick, a center for unaccompanied minor asylum seekers in Switzerland. It illustrates that Thomas, as

\footnotetext{
${ }^{1}$ In order to protect the anonymity of the research participants, all names of individuals, schools and places have been changed.

${ }^{2}$ According to the UNHCR, "[a]n unaccompanied child is a person who is under the age of eighteen, unless, under the law applicable to the child, majority is attained earlier and who is separated from both parents and is not being cared for by an adult who by law or custom has responsibility to do so" (UNHCR, 1997).
}

many other young refugees at Waldblick, is concerned with his educational situation, and especially with what kind of future this educational situation offers or does not offer. Such thoughts and - in a broader sense - UAMs' experiences in relation to education in Switzerland are in the focus of this article.

We ask, what does it mean for young unaccompanied refugees to get an education and how does having access or not having access to particular forms and spaces of education have part in their subject formations? In doing so, we draw on Judith Butler's work on processes of subject formation and bring it together with geographies of education's understanding of spaces of education as sites of power relations where identities are (re)produced (e.g., Valentine, 2000). There is widespread consensus that going to school is important for young refugees. Education can be protective, act as a coping mechanism, provide a sense of normality and stability and hope for the future, help overcome isolation and trauma, build resilience, help integration, and may also serve a social purpose by allowing them to meet 
new people and build friendships (Bird, 2003; Brownlees and Finch, 2010; Dryden-Peterson, 2011; Hek, 2005a, b; Kirk and Cassity, 2007; Machel, 1996; Matthews, 2008; Mosselson, 2006; Pascual, 2003; Sinclair, 2001; Sirriyeh, 2010; Walker, 2011). Despite this recognized importance of education and the children's right to education (guaranteed by the Convention on the Rights of the Child, UNICEF, 1989, and other legal frameworks), access to education is not given in every case as UAMs are subject not only to children's rights but also to their host country's asylum legislation. These two legal frameworks may be contradictory and are responsible for a wide range of quality and forms of education (Brownlees and Finch, 2010; Christie and Sidhu, 2006). Therefore, educational experiences of young refugees are also diverse. However, the existing literature on education for refugees rarely distinguishes between UAMs and other refugee children. This is particularly problematic given the sharp increase in the numbers of asylum applications by UAMs over the last years: Globally, the numbers rose from 25300 applications in 2013 and 34300 in 2014 to 98400 in 2015 (UNHCR, 2016). In the same years, Switzerland received 346 (2013), 795 (2014), and 2736 (2015) applications (SEM Staatssekretariat für Migration, 2016).

Based on ethnographic research in a center in Switzerland where exclusively UAMs aged 12 and older live, we focus on UAMs' educational expectations and experiences in order to show how processes through which one becomes a subject in the context of refugee education are at work and how such processes can be interwoven with feelings of belonging. We point out that attending an "internal school" 3 has the potential risk that UAMs perceive themselves as "others" without access to the mainstream educational system. However, we argue that although at first glance the category "unaccompanied minor asylum seeker" seems to dominate and determine the formation of UAMs' possible educational subjects and feelings of belonging, these subject formations and feelings of belonging in the highly regulated field of UAMs' education are far more complex and fluid. To capture this complexity and fluidity, we draw on geographies of education and understand spaces of education as sites of power relations where identities are (re)produced and can be viewed as "scaled-down versions of wider socio-spatial relations and constructions" (Kraftl, 2013:25; Valentine, 2000). Therefore, schools can be seen as "spaces distinct from, but embedded within, the context of everyday life" (Ansell, 2002:180) and connected to other, informal educational spaces (Valentine, 2000). Such a perspective on educational spaces helps to understand UAMs' educational experiences as these experiences are entangled with the demands of UAMs' everyday lives.

The remainder of the paper is structured as follows. After a brief review of the recent literature on education for refugees, we point out how we approach the interplay of ed-

\footnotetext{
${ }^{3}$ A school in a center for UAMs.
}

ucational spaces and refugees' subjectivities by drawing on a post-structuralist subject. This is followed by a section in which we outline our methodological framework and provide a glimpse into life at Waldblick, a center for UAMs. Drawing on ethnographic material, we then show how UAMs' positionalities change in relation to particular educational spaces and discuss particular challenges for UAMs emerging out of these arrangements.

\section{Education for refugees}

Education for refugees is a topic of interest in several disciplines. The literature can broadly be distinguished in two main fields. On the one hand, there is the literature engaged with the situation in the "global South", focusing on the provision of education (Dryden-Peterson, 2011; Sinclair, 2001). On the other hand, there is a body of literature concerned with the educational situation of refugees in the "global North" (countries of resettlement or asylumseeking). While some authors claim that refugee education in these countries of arrival is still under-researched (Uptin et al., 2016), there has been an increase in research on the topic lately, with a focus on access to education and the quality thereof (Christie and Sidhu, 2006; Dennis, 2002; Kirk and Cassity, 2007; Schwaiger and Neumann, 2014; Walker, 2011; Woods, 2009), including language acquisition (Koyama, 2013; Woods, 2009), inclusive education (Taylor and Sidhu, 2012), and the influence of education on the settlement process (Hek, 2005b; Matthews, 2008). However, this research is mostly concerned with young refugees in general (both accompanied and unaccompanied) and rarely focuses on the specific situation of UAMs.

An important topic in research on education for refugees is the meaning of having access to and participating in education. It is argued that education supports the integration of young refugees as it helps to develop their confidence and skills to improve their chances in the country of arrival. Further, it can help to reduce isolation experienced by many young refugees (Walker, 2011). For many, attending school is part of their imagined future and for some linked to their ambitions to achieve higher qualifications (Brownlees and Finch, 2010; Hek, 2005b). Having the capacity to imagine a future during the process of asylum, which is often experienced as "waiting time", is important for the subjective wellbeing of young refugees (Allsopp et al., 2015; Vitus, 2010). However, access to education is often interlinked with the status of refugees (refugees vs. asylum seekers vs. persons whose asylum claim had been denied, etc.) and different permits lead to different entitlements and access (Brownlees and Finch, 2010; Christie and Sidhu, 2006).

While in Germany, questions of access to (compulsory) schooling are critically discussed (Behrensen and Westphal, 2009; Nickel-Schampier, 2016), in Switzerland it is mostly access to post-compulsory education that is seen as problem- 
atic (Antony, 2010; Friedli, 2014; Kurt et al., 2014; Mey and Keller, 2016). As long as the young refugees are of compulsory school age, they can access educational structures. However, as our empirical data show, if one takes a closer look at these educational structures, one discovers that processes of exclusion are also at work when it comes to compulsory education, albeit more subtle ones. Therefore, if we focus on the meaning of access to education, it is important to clarify what kind of education is in the focus. Experiences at mainstream school often differ from experiences at educational programs designed particularly for young asylum seekers or young migrants. Educational arrangements in which young refugees mainly attend language courses, or attend school at the asylum center, are seen as a barrier to meeting young people who are not asylum seekers and to making friends with people from the host country (Brownlees and Finch, 2010; Vitus, 2010). Therefore, while language and/or integration courses for some youth become important structures, giving them a sense of normality and stability as well as offering something they can aim for and focus on, for others such educational arrangements give a structure but fail to give them hope for the future and are seen as a barrier to tracking their ambitions (Brownlees and Finch, 2010).

Educational spaces are complex sites which provide for some young refugees a primary place to belong (Cassity, 2007; Hastings, 2012). Drawing on research with male adolescent refugees in the UK, Hastings (2012) identified several factors - experienced by the refugees in educational spaces - contributing to a sense of belonging: "Learning the language, getting to know and be known by people around them, increasing familiarity with their environment and being listened to and respected by others" (Hastings, 2012:342). The development of such a sense of belonging arises from experiences of being with others and sharing everyday practices and is neither rooted in nor reducible to a single shared identity or a legal status of having citizenship (Nagel, 2011; Cassity, 2007; Wiseman, 2015). However, schools can also become places of feeling excluded as young refugees sometimes experience bullying about their behavior or lack of knowledge (Hastings, 2012).

However, despite the reference to diverse educational experiences of young refugees in relation to particular spaces of education, the body of refugee education research has paid scant attention to the significance of the interplay of space, education, and processes of subject formation. Therefore, in the next section, we turn to debates in geographies of education, which offer sophisticated discussions about spatiality in education and learning but rarely focus on refugee education ${ }^{4}$.

\footnotetext{
${ }^{4}$ However, two recent exceptions are the PhD projects by Murray (2016) and Shuttleworth (2016) focusing on refugee education.
}

\section{The interplay of space, education, and subject formation}

A significant part of the discussions in geographies of education is embedded in a relational thinking of space, whereby both space and subjects are conceptualized as fluid, as a complex of interacting social relations (Massey, 2005). It draws attention to schools and learning arrangements as more than discrete entities (Ansell, 2002; Holloway and Jöns, 2012), as ongoing productions always emerging out of entities (including human and non-human), depending on each other and embedded in specific power constellations (Massey, 2005). Learning arrangements and schools become therefore powerfilled spaces of negotiations which are shaped by and which are shaping wider social processes and can be viewed as related to various spaces including non-educational spaces (Holloway et al., 2010; Holloway and Jöns, 2012; Kraftl, 2013; Waters, 2016). Valentine (2000), for instance, explores how young people's identities are embedded and permanently reproduced not only on intersections of the formal (represented through official structures such as curricula and timetables) and the informal world of schools (such as peer group cultures) but also in relation to the parental home. In so doing, she highlights connections between home and educational spaces and shows how practices and norms in each are a part of young people's negotiations of identities (Holloway et al., 2010). Therefore, she argues that spaces of education go beyond classrooms and schools and can be alive in socio-spatial settings, which often are not seen as part of educational spaces (Valentine, 2000). In our paper, we bring a relational thinking of spaces of education as represented in the aforementioned literature, in particular a thinking of connectivity of spaces and co-constitution of space and identity, together with Judith Butler's work on subjection, in which "“subjection' signifies the process of becoming subordinated by power as well as the process of becoming a subject" (Butler, 1997:2).

Drawing on Judith Butler's work on processes of "subjection as the simultaneous subordination and forming of the subject" (Butler, 1997:7), Bronwyn Davies (2006) highlights how subjection can be approached and is at work in the context of education. For instance, she sheds light on how the curriculum can be seen as subjecting pupils at the same time as the pupils gain power by mastery of the curriculum. Drawing on an analysis of the Queensland English Syllabus it becomes visible that the student constituted in the syllabus is "a subject who is, at one and the same time, required to master the practices of literacy mandated in the syllabus, while becoming subjected to the requirements of these practices" (Davies, 2006:429-430). The syllabus, Davies (2006:430) argues, "presents itself as liberating students through literacy in order to become individuals". Davies focuses on the ambivalence of mastery and submission, which, as Butler pointed out, take place simultaneously (Davies, 2006). Butler (1997:116) writes "the lived simultaneity of submission and 
mastery, and mastery as submission, is the condition of possibility for the emergence of the subject". And in this process of becoming a subject, subjection consists of a "fundamental dependency on a discourse we never chose, but that, paradoxically, initiates and sustains our agency" (Butler, 1997:2). In doing so, she makes explicit that such a subject formation depends on (external) power and writes "if, following Foucault, we understand power as forming the subject as well, as providing the very condition of its existence and the trajectory of its desire, then power is not simply what we oppose but also, in a strong sense, what we depend on for our existence and what we harbor and preserve in the beings that we are" (Butler, 1997:2). Therefore, the ongoing process of forming a subject is always entangled in these power conditions, it reiterates, conforms, or subverts them. Butler - and so Davies in her translation of Butler's thoughts into the context of education - further points out that a mutual act of recognition is central to the simultaneous processes of submission and mastery in the formation of the subject. It is through this mutual act of recognition that subjects afford each other the status of a viable subject (Davies, 2006:427). Therefore, subjects are not passively exposed to power nor is the accomplishment of mastery simply an act of willing submission (Davies, 2006:433). Davies, for instance, highlights that students' accomplishment of mastery may involve complex negotiations and hard work. In our paper, we will draw on such post-structural thinking of subject formations in order to highlight how access (or denied access) to particular spaces of education as well as mutual acts of recognition in spaces of education are connected to processes of subjection in the case of UAMs in Switzerland.

\section{The study}

This article is based on ethnographic field research at Waldblick, a center for UAMs aged 12 years and older ${ }^{5}$ in Switzerland. From August 2011 until February 2014, Barbara regularly (first weekly, later bi-weekly) visited Waldblick in order to conduct the empirical research as part of her $\mathrm{PhD}$ project on the everyday lives of UAMs in Switzerland. Therefore, the "I" in the field notes refers to her. During these afternoons, she talked to UAMs as well as staff members and engaged in leisure time activities with the young people. This was, on the one hand, important to get to know the young people and to establish mutual trust, which is important when working with asylum seekers and refugees (Kohli, 2006; Thomas and Byford, 2003; White and Bushin, 2011). On the other hand, these afternoons also served to collect data through participant observation and informal conversations with UAMs and staff, recorded as field notes. Further, some semi-structured interviews with UAMs were conducted. If the interviewees

\footnotetext{
${ }^{5}$ Younger children are usually placed with foster families, unless there are older siblings living at Waldblick and able to take care of them.
}

agreed, the interviews were recorded and subsequently transcribed. Data were analyzed through coding in an abductive logic, meaning combining codes emerging from data and codes deducted from literature (Kelle, 2005).

Barbara introduced herself at Waldblick as someone writing a book on unaccompanied minors. As there were young people and new staff members arriving frequently, she introduced herself regularly. Sometimes, newly arrived young people also heard from others that she was writing this book and thus came to find her to ask about it. Despite these frequent introductions, it also happened that someone thought she was a volunteer offering leisure time activities or that she was doing an internship or community service at the center.

Waldblick is a stately old building located on the outskirts of a mid-sized Swiss town henceforth called Wieslikon. Most of the young people living at Waldblick are still in the asylum procedure (Permit $\mathrm{N}$ ), meaning that their asylum claims have not been answered yet. In some cases, asylum (Permit B) or temporary admission (Permit F) had been granted. ${ }^{6}$ However, despite their different asylum statuses, concerning living together at Waldblick, the same set of rules applies to all of them. At Waldblick, the young people are expected to live relatively independently. They are responsible for cleaning and receive their social welfare ${ }^{7}$ once a week and are then responsible for budgeting, buying and preparing their own food, etc. Social workers are responsible for the day-to-day support of the young people.

In Switzerland, only some cantons have specialized centers for UAMs such as Waldblick. These centers have several advantages: for example, the staff, through their experience in working with UAMs, become sensitive to the situation of UAMs and their needs ${ }^{8}$, and the UAMs do not have to live together with adult asylum seekers. However, in the realm of education, a spatial concentration of UAMs due to such a center may have negative effects. As the large number of UAMs was perceived as a challenge by the local public school at Sekundarstufe $I^{9}$, an internal school (which most UAMs living at Waldblick attend) was established. In line with the educational law (Volksschulgesetz) of the canton, this internal school is conceptualized as an Aufnahmeklasse $^{10}$. One of the main goals of such Aufnahmeklassen is to learn the German language and improve German literacy competency. When these competencies reach a certain

\footnotetext{
${ }^{6}$ For a list of the residence permits for non-EU/EFTA nationals, see https://www.sem.admin.ch/sem/en/home/themen/aufenthalt/ nicht_eu_efta.html (last access: 9 May 2016).

${ }^{7}$ How much money they receive depends on the asylum status and their age.

${ }^{8}$ The staff are mainly social workers. In Switzerland, no special qualification or training for working with UAMs existed at the time of research.

${ }^{9}$ Lower secondary school.

${ }^{10}$ Reception class.
} 
level, the pupils should be transferred to mainstream classes at Sekundarstufe I.

Regarding previous education, there are enormous differences among UAMs. Some are illiterate, having never been to school, while others received a good education in their country of origin. To take those variations into account, the internal school at Waldblick consists of three levels, all of which are designed as Aufnahmeklassen. If the UAMs' German competencies and their general level of education are high enough, they can take a test in order to attend the local public secondary school. Only a minority of the UAMs living at Waldblick reach the requirements to be allowed to attend public school, even though most of the young people Barbara talked to have this goal.

In the next sections, we focus mainly on Mohammed, Reza, and Merhawit, three young people living at Waldblick. We will move with them through several spaces of education: from Aufnahmeklasse at the internal school to mainstream classes at Sekundarstufe I to non-school spaces which are connected to school by social networks. In doing so, we will show how educational experiences can change in relation to varying educational spaces, how Mohammed, Reza, and Merhawit perceive themselves to be subjected by the educational system, and how the educational system and their educational experiences influence their belonging and their subjectivities.

\section{At internal school}

When Barbara met Mohammed from Afghanistan, he was 14 years old and had only been living in Switzerland about half a year. He had attended school in Afghanistan until he left the country at the age of 13 and had been on the move for a few months. When they met, Mohammed was attending the internal school at Waldblick. He had the firm goal of attending the local public school at Sekundarstufe I and studied a lot in his free time in order to achieve this goal. Many times, when Barbara was at Waldblick on Wednesday afternoon, Mohammed came to find her to ask questions about his homework or about the German language. Similar were the experiences she shared with Reza. He stressed that he had a good education in Iran, where he attended the highest school level. He had the firm goal of attending Gymnasium $^{11}$ in Switzerland and then studying physics. Once he said, "I only want to learn, eat, and sleep, nothing else". When they talked, he often used his smartphone to check and practice declensions. Further, he had a dictionary on his phone and repeatedly asked Barbara to explain words to him. Mohammed and Reza were determined to learn as much as possible. Therefore, they criticized the internal school's main focus on German language acquisition. Other subjects such as mathematics were only taught marginally. And when they did have mathematics, it was only very simple additions and

\footnotetext{
${ }^{11}$ Baccalaureate school.
}

subtractions, not "real" mathematics as they were taught at school before their flight, Reza explained. He was thus afraid that by the time his German was good enough to attend public school at Sekundarstufe I, he would have missed too much in the other subjects to pass his classes. Other young people shared this critique. In particular, they worried about their chances to go to public school at Sekundarstufe I or to find an apprenticeship position in the future if they attended the internal school (Aufnahmeklasse) for too long. These concerns are reflected in the fact that many of the young people attend the internal school (Aufnahmeklasse) during their entire stay at Waldblick, which may well be several years. Originally, the Aufnahmeklassen were designed with the idea that the young people would attend them for a maximum of 6 months and then should be transferred to Sekundarschule or attend a different educational program. However, as the staff at Waldblick explained, the relationships with both the town of Wieslikon and the local public school at Sekundarstufe I, Wiesenmatte, are important and therefore it was agreed that only the ones with sufficient knowledge of German and other subjects (proven by successfully completing the entry test) would be sent to Wiesenmatte. Further, staff explained that it depended not only on the young people's educational achievement but also on other factors: Waldblick only sends hardworking and "well-behaved" pupils to Wiesenmatte, hoping that they would reflect positively on Waldblick.

Drawing on Davies' attempt to translate Butler's theory of subjection into the context of education allows us to highlight some processes of subjection which are experienced by Mohammed and Reza in the context of the refugee-education arrangement at Waldblick. First of all, both perceive the educational arrangement at Waldblick, which is particularly tailored to UAMs, as an arrangement that does not recognize their previously acquired educational knowledge. This is due on the one hand to the internal school's focus on learning German and on the other hand to the fact that young people who received formal education prior to their arrival in Switzerland had to attend classes together with others who were illiterate. The position of a well-educated pupil eager to learn as much as possible (German and other subjects), which they wanted to take over, did not seem to be viable; it is simply not offered in an educational system where they have to attend Aufnahmeklassen - often for a long time. This absence of recognition by the educational system seems to dominate and determine processes of becoming a subject in the field of education. However, in the perception of some young people Barbara talked to, the educational arrangement at Waldblick offers a way to be recognized as an appropriate subject for mainstream school: mastering German at Level A2 of the Common European Framework of Reference for Languages (CEFR) and passing the entry test of the local Sekundarschule Wiesenmatte while still being of compulsory school age - the way chosen by Mohammed. Drawing on a Davies-Butlerian perspective brings into sharper focus the complexity and simultaneity of power and agency in the pro- 
cess of subjection as well as the simultaneity of submission and mastery, which promises recognition - all at work on the path chosen by Mohammed. By attempting to master what was asked of him in order to become the promised (by the system) and desired (by him) subject, the subject who is able to attend mainstream school, he complied with the requirements of the Swiss education system. He accepted that in order to be recognized as "good enough" to attend mainstream school, he had to fulfill certain criteria (visiting the internal school, sufficient knowledge of the German language in order to follow the mainstream curriculum, as well as sufficient knowledge in other subjects such as mathematics).

\section{At mainstream school}

When Mohammed had successfully passed the entry exam for the mainstream school, he was allowed to attend Sekundarschule Wiesenmatte, which was a new educational space for him. Mastering the test was a source of empowerment for him and he seemed very excited about the new opportunities that this presented him with. Being able to fulfill the criteria to attend mainstream school allowed him to take part in a practice constituting his own subjectivity as "mainstream pupil". He said that he really liked the fact that he, in the achieved position of a mainstream pupil, was now taught more subjects than at Waldblick. Through attending Wiesenmatte, he was, at least in his perception, now on track to receive a mainstream education diploma and to find an apprenticeship position after school and, ultimately, a "better" future. However, as we will see by following Mohammed's experiences, processes of subject formation are ongoing and subjections can vary in different contexts.

Educational spaces such as Wiesenmatte are far more than literacy and curriculum "delivering machines" (Matthews, 2008:42). They have the potential to become spaces where refugees can develop a sense of belonging through experiences such as being recognized by others (teachers and classmates for instance) and therefore participate in a mutual act of recognition, in which subjects afford each other the status of a viable subject (Cassity, 2007; Hastings, 2012). However, at the same time such spaces of education include the risk of producing feelings of isolation and not belonging, as refugees may face everyday situations they do not know how to deal with (Cassity, 2007; Walker, 2011).

Mohammed, who was 16 years old at the time, and attending Sekundarschule together with 13- and 14-year-olds, made some rather disappointed comments about his classmates. He said that they were still children, talking about things that were not of interest to a 16-year-old and he therefore did not like talking to them.

Similarly, Merhawit, a 16-year old girl from Eritrea who passed the test and attended Wiesenmatte for a while, also criticized the age difference between her and the other pupils:
I am going outside, where Merhawit is smoking. We talk for a while (...). At the moment, she is looking for a job at a restaurant, in care work, or as a maid in a hotel ${ }^{12}$. She doesn't attend Wiesenmatte anymore, but is back at Waldblick's school. The reason for this is that she had a "timeout"13 at Wiesenmatte, because she had been skipping school. I ask why she skipped school and she says that it had just been too boring. Especially with the classmates, because they were about 14 years old and she is already 16 . She says she just wasn't comfortable. Now she's trying to find a job, thinking that would be better for her (field notes 19 September 2012, Waldblick).

For both Mohammed and Merhawit, attending Wiesenmatte had been a very important goal and many hopes and expectations were tied to it. However, most of these hopes contrasted with the experiences they made. They still seemed to think that, education-wise, mainstream school was better than the internal school. Mohammed very excitedly told Barbara that he was learning much more at Wiesenmatte than at the internal school. He appreciated that in addition to German he was now also taught English, and he said that mathematics was rather easy for him. He presented the curricular knowledge as an area where he did not have any problems. The more challenging part was establishing relationships with peers: the hopes regarding meeting other people were not fulfilled to the extent assumed before. This contrasts with what literature stresses as an important function of education for refugees: making new friends (Brownlees and Finch, 2010; Hek, 2005b; Matthews, 2008; Stoecklin et al., 2013; Walker, 2011). Both Mohammed and Merhawit presented the age difference as the main reason for not spending much time with their classmates and for their feelings of not belonging. Their specific experiences as UAMs before and during the flight, as well as in Switzerland where they are living without their parents and thus responsible for themselves, may make the difference in life experience greater than the biological age difference. Therefore, the biological age difference in their narrations may represent the difference in life experience and the completely different lives they lead. This may help to understand Merhawit's decision to return to the internal school and to start looking for a job instead of attending the mainstream school any longer, a decision that hardly seems based simply on the age difference between her and

\footnotetext{
${ }^{12}$ Interestingly, Merhawit mentions jobs that are still mostly done by women (Schwiter et al., 2014). This raises the question as to what degree mechanisms leading to gendered segregation are at work when refugees enter the labor market. Pursuing this issue, however, would go beyond the scope of this article.

${ }^{13}$ The "timeout" is a temporary suspension from school for disciplinary reasons. The measure is a cantonal practice (Bildungsdirektion Kanton xx, n.d.).
} 
her classmates, considering that attending Wiesenmatte had previously been a strong desire of hers.

Mohammed briefly mentioned that he was "the foreigner" at school and that his classmates did not visit him at Waldblick because their parents thought the young people at Waldblick lived in Switzerland because they had done bad things in their country of origin. We can therefore assume that stereotypes about refugees and asylum seekers also play a role in the difficulty to establish relationships with peers. Interestingly, however, both Mohammed and Merhawit hardly mentioned this or other anticipated reasons such as language difficulties or disinterest, which - in contrast to age difference - are well known in the literature on refugee education. They both stressed mainly the age difference in their explanations. To focus on the age difference may be a strategy they employ in order to present themselves as actively choosing not to spend time with their classmates instead of as trying to make friends but their classmates deciding not to spend time with them.

\section{Doing grocery shopping or being subjected in the web of connections built up at mainstream school}

In geographies of education it is argued that spaces of education are more than discrete spaces. For instance, friendships and relations built up in classrooms can gain different meanings on lunch breaks or in the neighborhood (Thomas, 2005; Valentine, 2000). Therefore, it is suggested that "rather than focusing on education within specific sites, we need to trace the webs of connections between, for example, home and school, showing how sociospatial practices in each shape children, youth and families' experiences of both sites" (Holloway et al., 2010:595). Following Mohammed's web of connections built up at mainstream school to spaces beyond the discrete site of school gives us insights into how subjection can vary in different contexts and, at the same time, how it can be embedded in a web of practices from diverse spaces.

The supermarket turned out to be a space where the web of connections becomes meaningful. As UAMs' parents are absent, they are themselves responsible for meeting their basic needs such as buying and preparing food. Grocery shopping is thus part of Mohammed's daily routine, marking him as different from other young people.

Barbara: So the grocery shopping, you always do that with Nima and Abdullah (two other young men living at Waldblick)?

Mohammed: Yes, but we're very ashamed of it.

Barbara: Why?

Mohammed: Because 15-year-olds in Switzerland don't do their grocery shopping on their own. For example, when my pals hang around outside the supermarket-

Barbara: Your friends from school?

Mohammed: Yes. They say "look, he's doing the shopping on his own" and stuff.

The quote indicates that at the supermarket Mohammed experiences a coming together of his subjectivity as a UAM performed through a normal task and responsibility for a UAM (grocery shopping) with his subjectivity as a mainstream pupil performed through identifying himself and being identified as a classmate of the 15-year-olds hanging around in front of the supermarket. Mohammed experiences this coming together as a discontinuity and feels embarrassed. He feels that the practice of doing his own grocery shopping sets him aside from his classmates, marking him as different from them. In the classroom, he is older and disidentifies with his classmates in terms of age and age-appropriate interests but at least all of them share the practices of attending Wiesenmatte and following the same curriculum, which supports his performance as a mainstream pupil and works as a source of belonging to the class; in class, they follow the same submission-mastery-recognition complex in relation to the academic curriculum. However, he presents his doing at the supermarket as being far away from the doing of his classmates and - based on these doings - they do not seem to be able to (re)produce any kind of shared subjectivity. Instead, the opposite happens. It seems that attending Wiesenmatte was an empowering experience regarding his position among the other young people at Waldblick. However, meeting his classmates in front of the supermarket turned his web of connections built up at Wiesenmatte into a resource of marking him as different from them. His narration included no passages indicating that there was any common ground of mutual recognition in this new socio-spatial setting or any shared practices allowing for belonging.

\section{Conclusions}

In bringing a relational thinking of spaces of education together with Judith Butler's work on subjection, we have sought to show how processes of becoming subordinated by power as well as processes of becoming a subject are at work in the context of refugee education, how such processes can be interwoven with feelings of belonging, and how significant space can be in these processes. The existing literature on education for refugees rarely distinguishes between UAMs and other refugee children. While some aspects of education may be similar (e.g., getting acquainted with a (new) educational system and having to learn a new language), we argue that there are also vast differences as the specific situation of UAMs (in our case, living in a collective accommoda- 
tion, attending the internal school for a long time, living without their parents and therefore being responsible for many daily tasks such as cooking, shopping, etc.) indeed influences their educational experiences. Through the examples of Mohammed and Reza we have demonstrated how being subjected as UAMs through the educational system can hinder the recognition of UAMs' previously acquired educational knowledge. Therefore, transitions from Aufnahmeklasse to mainstream school should not be postponed as it is often the case at Waldblick. Instead, attending educational arrangements outside the mainstream school should be time-bound (Walker, 2011). In literature on refugee education, learning arrangements with a strong focus on the official language are criticized as they fail in giving the young refugees hopes for the future. The development of courses "that combine the learning of English (official language) with subject-based courses so that unaccompanied or separated migrant children can build on the academic knowledge they have previously acquired" is demanded (Brownlees and Finch, 2010:7) - a demand we strongly support based on our research results.

Using a Davies-Butlerian perspective helped us to shed light on how Mohammed was later nevertheless able to take part in a practice constituting his own subjectivity as "mainstream pupil" through simultaneous mastery of and submission to the Swiss educational system. Mohammed's and Merhawit's experiences at mainstream school show how processes of subjection are interwoven with feelings of belonging: while they were able to achieve belonging in terms of curricular knowledge, the age difference (which we assume they present as a proxy for the difference in life experience) between them and their classmates at Wiesenmatte led to disappointed hopes regarding making friends and to feelings of not belonging. This feeling of not belonging experienced at mainstream school seems to be caused by having the life experiences of a UAM and stereotypes about refugees and asylum seekers. Further, it appears to be reproduced by everyday tasks and responsibilities for UAMs such as buying their groceries. As long as many UAMs live in collective accommodations and are excluded from mainstream school, it is hard to overcome stereotypes and to really engage with their biographies and everyday lives. To integrate in principle all UAMs into mainstream schools after a time-bound phase in Aufnahmeklassen - and to support such an integration through trained volunteers or professionals who work in a productive way with fears and doubts, barriers that impede interaction, feelings of anxiety, and excessive demands - could be a way to turn spaces of education into stronger spaces of belonging.

Data availability. Due to the sensitive nature of asylum issues, the data are not publicly available. Further, research participants did not consent to the distribution of interview data.
Author contributions. The first author did the field research as part of her $\mathrm{PhD}$ project. Both authors prepared the manuscript together $(50: 50)$.

Competing interests. The authors declare that they have no conflict of interest.

Acknowledgements. We would like to thank the team of Waldblick, a center for unaccompanied minor asylum seekers, for allowing Barbara to do research at Waldblick and all unaccompanied minor asylum seekers who shared their time and stories with her. Further, we would like to thank the two anonymous reviewers for their helpful comments and feedback as well as Itta Bauer and the members of "Passagen - Forschungskreis Migration und Geschlecht" for their valuable comments on an earlier draft of this paper.

Edited by: M. Houssay-Holzschuch

Reviewed by: two anonymous referees

\section{References}

Allsopp, J., Chase, E., and Mitchell, M.: The tactics of time and status: young people's experiences of building futures while subject to immigration control in Britain, J. Refug. Stud., 28, 163-182, doi:10.1093/jrs/feu031, 2015.

Ansell, N.: 'Of course we must be equal, but...': imagining gendered futures in two rural southern African secondary schools, Geoforum, 33, 179-194, 2002.

Antony, E.: Les mineurs non accompagnés séjournant en Suisse: quelles perspectives d'avenir?, Master Thesis, Institut Universitaire Kurt Bösch, Sion., 2010.

Behrensen, B. and Westphal, M.: Junge Flüchtlinge - ein blinder Fleck in der Migrations- und Bildungsforschung. Bildung junger Flüchtlinge als Randthema in der migrationspolitischen Diskussion, in: Bildung für junge Flüchtlinge - ein Menschenrecht: Erfahrungen, Grundlagen und Perspektiven, edited by: Krappmann, L., Lob-Hüdepohl, A., Bohmeyer, A., and Kurzke-Maasmeier, S., 45-58, W. Bertelsmann Verlag, Bielefeld, 2009.

Bildungsdirektion Kanton xx: Umsetzung Volksschulgesetz. Merkblatt Schulpflicht, Disziplinarmassnahmen und Elternpflichten, Bildungsdirektion Kanton xx, Volksschulamt, XX., n.d.

Bird, L.: Surviving school: Education for refugee children from Rwanda 1994-1996, International Institute for Educational Planning UNESCO, Paris. available at: http: //www.ineesite.org/uploads/files/resources/Surving_School-_ Education_for_refugee_children_from_Rwanda_1994-1996.pdf (last access: 8 April 2013), 2003.

Brownlees, L. and Finch, N.: Levelling the playing field. A UNICEF UK report into provision of services to unaccompanied or separated migrant children in three local authority areas in England, UNICEF UK, London, 2010.

Butler, J.: The psychic life of power: Theories in subjection, Stanford University Press, Stanford, 1997. 
Cassity, E.: Voices shaping education: Young African refugees in Western Sydney high schools, Int. Educ. J. Comp. Perspect., 8, 91-104, 2007.

Christie, P. and Sidhu, R.: Governmentality and "fearless speech": framing the education of asylum seeker and refugee children in Australia, Oxf. Rev. Educ., 32, 449-465, doi:10.1080/03054980600884177, 2006.

Davies, B.: Subjectification: the relevance of Butler's analysis for education, Br. J. Sociol. Educ., 27, 425-438, doi:10.1080/01425690600802907, 2006.

Dennis, J.: A case for change. How refugee children in England are missing out, The Children's Society, Save the Children and Refugee Council, London, 2002.

Dryden-Peterson, S.: Refugee education. A global review, UNHCR, Geneva, 2011.

Friedli, E.: Der Zugang zu Bildung für unbegleitete minderjährige Asylsuchende nach der obligatorischen Schulzeit in der Schweiz. Ein Vergleich zwischen den Kantonen Zürich und Aargau, Forschungsarbeit, Universität Luzern, Luzern, 2014.

Hastings, C.: The experience of male adolescent refugees during their transfer and adaptation to a UK secondary school, Educ. Psychol. Pract., 28, 335-351, doi:10.1080/02667363.2012.684342, 2012.

Hek, R.: The experiences and needs of refugee and asylum seeking children in the UK: A literature review, Research Report RR635, University of Birmingham, available at: http://dera.ioe. ac.uk/5398/1/RR635.pdf (last access: 2 April 2013), 2005a.

Hek, R.: The role of education in the settlement of young refugees in the UK: The experiences of young refugees, Practice, 17, 157171, doi:10.1080/09503150500285115, 2005b.

Holloway, S. L. and Jöns, H.: Geographies of education and learning, Trans. Inst. Br. Geogr., 37, 482-488, 2012.

Holloway, S. L., Hubbard, P., Jöns, H., and Pimlott-Wilson, H.: Geographies of education and the significance of children, youth and families, Prog. Hum. Geog., 34, 583-600, doi:10.1177/0309132510362601, 2010.

Kelle, U.: "Emergence" vs. "forcing" of empirical data? A crucial problem of "Grounded Theory" reconsidered, Forum Qual. Sozialforschung Forum Qual. Soc. Res., 6, available at: http://www.qualitative-research.net/index.php/fqs/ article/view/467 (last access: 20 July 2016), 2005.

Kirk, J. and Cassity, E.: Minimum standards for quality education for refugee youth, Youth Stud. Aust., 26, 50-56, 2007.

Kohli, R. K. S.: The sound of silence: Listening to what unaccompanied asylum-seeking children say and do not say, Br. J. Soc. Work, 36, 707-721, doi:10.1093/bjsw/bch305, 2006.

Koyama, J.: Resettling notions of social mobility: locating refugees as "educable" and "employable", Br. J. Sociol. Educ., 34, 947965, doi:10.1080/01425692.2013.816033, 2013.

Kraftl, P.: Geographies of alternative education. Diverse learning spaces for children and young people, Policy Press, Bristol, 2013.

Kurt, S., Panicara, E., and Strickler, V.: Kinder und Jugendliche auf der Flucht. Die Situation von unbegleiteten minderjährigen Asylsuchenden in der Schweiz, Schweizerische Beobachungsstelle für Asyl- und Ausländerrecht, Bern, 2014.

Machel, G.: Promotion and protection of the rights of children: Impact of armed conflict on children, UNICEF, 1996.

Massey, D.: For space, Sage, London and Thousand Oaks, 2005.
Matthews, J.: Schooling and settlement: refugee education in Australia, Int. Stud. Sociol. Educ., 18, 31-45, doi:10.1080/09620210802195947, 2008.

Mey, E. and Keller, S.: Im Schnittfeld von Asylpolitik und Kindesschutz. Dringliche Herausforderungen im Umgang mit unbegleiteten minderjährigen Asylsuchenden, SozialAktuell, 4, 20-22, 2016.

Mosselson, J.: Roots \& Routes: A re-imagining of refugee identity constructions and the implications for schooling, Curr. Issues Comp. Educ., 9, 20-29, 2006.

Murray, R.: "Let the right one in". Transcending borders, barriers \& binaries; widening access to Higher Education for forced migrants, University of Sheffield, Sheffield, available at: https:// www.sheffield.ac.uk/geography/phd/pg/rebecca_murray, last access: 19 May 2016.

Nagel, C.: Belonging, in: A Companion to Social Geography, edited by: Del Casino, V. J., Thomas, M. E., Cloke, P., and Panelli, R., 108-124, Wiley-Blackwell, Chichester, available at: http://onlinelibrary.wiley.com/doi/10.1002/9781444395211. ch7/summary (last access: 5 August 2015), 2011.

Nickel-Schampier, T.: Unbegleitete minderjährige Flüchtlinge in Deutschland. Fachliche und ethische Herausforderungen für die Kinder- und Jugendhilfe, Neue Prax., 2, 170-183, 2016.

Pascual, M. J. V.: Key aspects about education for refugee children: refugee camp situation, Rev. Esp. Educ. Comp., 9, 225260, 2003.

Schwaiger, M. and Neumann, U.: Junge Flüchtlinge im allgemeinbildenden Schulsystem und die Anforderungen an Schule, Unterricht und Lehrkräfte, in: Inklusion auf Raten: Zur Teilhabe von Flüchtlingen an Ausbildung und Arbeit, edited by: Gag, M. and Voges, F., 60-79, Waxmann Verlag, Münster, New York, 2014.

Schwiter, K., Hupka-Brunner, S., Wehner, N., Huber, E., Kanji, S., Maihofer, A., and Bergman, M. M.: Warum sind Pflegefachmänner und Elektrikerinnen nach wie vor selten? Geschlechtersegregation in Ausbildungs- und Berufsverläufen junger Erwachsener in der Schweiz, Swiss J. Sociol., 40, 401-428, 2014.

SEM Staatssekretariat für Migration: Unbegleitete minderjährige Asylsuchende in der Schweiz (UMA). Vergleichstabelle 20132015, Schweizerische Eidgenossenschaft, Eidgenössisches Justiz- und Poizeidepartement EJPD, Staatssekretariat für Migration, Bern, 2016.

Shuttleworth, S.: Refugee children and spaces of education and language, University of Glasgow, Glasgow, available at: http:// www.gla.ac.uk/schools/ges/pgresearch/sophieshuttleworth/, last access: 19 May 2016.

Sinclair, M.: Education in emergencies, Learn. Future Refug. Educ. Dev. Ctries., 1-84, 2001.

Sirriyeh, A.: Home journeys: Im/mobilities in young refugee and asylum-seeking women's negotiations of home, Childhood, 17, 213-227, 2010.

Stoecklin, D., Scelsi, M., and Antony, E.: Statut et carrière des mineurs séparés en Suisse: objets d'intervention ou sujets de droits?, Swiss J. Sociol., 39, 575-592, 2013.

Taylor, S. and Sidhu, R. K.: Supporting refugee students in schools: what constitutes inclusive education?, Int. J. Incl. Educ., 16, 3956, doi:10.1080/13603110903560085, 2012.

Thomas, M. E.: "I think it's just natural": the spatiality of racial segregation at a US high school, Environ. Plann. A, 37, 12331248, 2005. 
Thomas, S. and Byford, S.: Research with unaccompanied children seeking asylum, Br. Med. J., 327, 1400-1402, doi:10.1136/bmj.327.7428.1400, 2003.

UNHCR: Guidelines on policies and procedures in dealing with unaccompanied children seeking asylum, UNHCR, Geneva, 1997.

UNHCR: Global Trends. Forced displacement in 2015, UNHCR, Geneva, available at: http://www.unhcr.org/statistics/ unhcrstats/576408cd7/unhcr-global-trends-2015.html, last access: 19 September 2016.

UNICEF: Convention on the Rights of the Child, available at: http:// www.ohchr.org/EN/ProfessionalInterest/Pages/CRC.aspx, 1989.

Uptin, J., Wright, J., and Harwood, V.: Finding education: Stories of how young former refugees constituted strategic identities in order to access school, Race Ethn. Educ., 19, 598-617, doi:10.1080/13613324.2014.885428, 2016.

Valentine, G.: Exploring children and young people's narratives of identity, Geoforum, 31, 257-267, 2000.

Vitus, K.: Waiting Time: The de-subjectification of children in Danish asylum centres, Childhood, 17, 26-42, 2010.
Walker, S.: Access Denied: refugee children and the exclusionary logic of the education system in England, Power Educ., 3, 210 223, doi:10.2304/power.2011.3.3.210, 2011.

Waters, J. L.: Education unbound? Enlivening debates with a mobilities perspective on learning, Prog. Hum. Geog., doi:10.1177/0309132516637908, 2016.

White, A. and Bushin, N.: More than methods: learning from research with children seeking asylum in Ireland, Popul. Space Place, 17, 326-337, doi:10.1002/psp.602, 2011.

Wiseman, J.: "If there is something mixed, it's gonna be nice" Young refugees in Glasgow and multicultural spaces of belonging, Draft paper for the workshop "Young divercities", Utrecht, 4-6 November 2015.

Woods, D. A.: Learning to be literate: issues of pedagogy for recently arrived refugee youth in Australia, Crit. Inq. Lang. Stud., 6, 81-101, doi:10.1080/15427580802679468, 2009. 